\title{
ДЕМОКРАТИЧНА ОРІЕНТОВАНІСТЬ ПОЛІТИКИ ДЕРЖАВИ В НАПРЯМІ ПУБЛІЧНОГО РЕФОРМУВАННЯ
}

\author{
Титаренко Л. М., Грішин О. В.
}

\section{ВСТУП}

Демократична орієнтованість політики держави розвивається на тлі інноваційних процесів в Україні, що вимагають нових рішень і дій. Як науковий концепт, що формує стратегію й реалізує інституалізацію публічного управління, демократично орієнтована політика увійшла в управлінську науку порівняно недавно, а академічний інтерес викликаний пошуком нових методологічних підходів до пояснення публічної політики в системі державного управління.

Вагомий внесок у дослідження проблематики інноваційного розвитку держави та формування іiі демократично орієнтованої політики зробили: В. Авер'янов, В. Бакуменко, Р. Войтович, Н. Гавкалова, Ю. Ковбасюк, А. Мельник, Р. Мельник, М. Міненко, О. Оболенський, М. Стадник, Ю. Сурмін, В. Шарий та ін. На їхню думку, розуміння орієнтованості політики країни, сутності публічного реформування як процесу, що здійснюється на основі волевиявлення громадян та реалізується суб'єктами, що здійснюють демократичні перетворення, цікаве та корисне для виконання державою суспільно важливих функцій ${ }^{1}$.

1 Авер'янов В.Б. Державне управління: Європейські стандарти, досвід та адміністративне право / В.Б. Авер'янов, В.А. Дерець, А.М. Школик та ін. ; за заг. ред. В.Б. Авер'янова. Київ : Юстиніан, 2007. 288 с.

Бакуменко В.Д. Публічне адміністрування як процес вироблення, прийняття та виконання управлінських рішень. Наукові розвідки з державного та муніцииального управління : зб. наук. пр. академії муніципального управління. № 1. (Б. м. : б. в.), 2015. С. 8-26.

Енциклопедичний словник з державного управління / уклад.: Ю.П. Сурмін, В.Д. Бакуменко, А.М. Михненко та ін. ; за ред. Ю.В. Ковбасюка, В.П. Трощинського, Ю.П. Сурміна. Київ : НАДУ, 2010. 820 с.

Войтович Р.В. Ефективність публічного управління в умовах пошуку нової геополітичної ідентичності України. Публічне управління: иляхи розвитку : матер. наук.-практ. конф. за міжнар. уч. (26 листопада 2014 р., м. Київ): у 2 т. Т. 1 / за наук. ред. Ю.В. Ковбасюка, С.А. Романюка, О.Ю. Оболенського. Київ : НАДУ, 2014. Т. 1. С. 30-34. 
Реалізація суспільно важливих функцій у державно-службових відносинах - це найважливіший елемент інституту державної служби, оскільки на цьому часовому відрізку реалізується демократична спрямованість політики держави, що передбачає послідовну зміну багатьох чинників. Перш за все це означає рівні права громадян на зайняття будь-якої посади в органах державної влади відповідно до своїх знань, здібностей i професійної підготовки. Крім того, проголошення принципу рівного доступу громадян до державної служби співвідноситься з наявністю фахової освіти, досвіду роботи i кваліфікації, що $є$ гарантією від протиправних дій органів державної влади чи посадових осіб ${ }^{2}$.

Загалом, останнім часом відбувається інтенсивний процес становлення нової європейської моделі державної політики, що орієнтує вітчизняну управлінську спільноту на побудову сучасної країни 3 дотриманням принципів державної служби, забезпечення законності в системі iii функціонування. При цьому необхідність розгляду демократично орієнтованої політики держави в теоретикометодологічному та практичному вимірах зумовлена низкою причин, які пов'язані зі зміною стану якості та функціональних можливостей сучасних інституцій управління в умовах вітчизняного простору. Проте праць, які б визначали стратегічні орієнтири публічного управління вітчизняної сфери, не досить, що потребує наукового осмислення.

Стадник М.М. Публічне управління як чинник сталого розвитку / М.М. Стадник, В.С. Дяченко. за наук. ред. Ю.В. Ковбасюка, С.А. Романюка, О.Ю. Оболенського. Публічне управління: иляхи розвитку: матер. наук.-практ. конф. за міжнар. уч. (26 листопада 2014 р., м. Київ) : у 2 т. Т. 1. Київ : НАДУ, 2014. C. 39-41.

2 Вернудіна І.В. Особливості публічного управління в Україні: цивілізаційний поступ та сучасні виклики. Публічне управління: шляхи розвитку: матер. наук.-практ. конф. за міжнар. уч. (26 листопада 2014 р., м. Київ) : у 2 т. Т. 1 / за наук. ред. Ю.В. Ковбасюка, С.А. Романюка, О.Ю. Оболенського. Київ : НАДУ, 2014. С. 30-32.

Мельник Р.С. Категорія «публічне управління» у новій інтерпретації. Адміністративне право і прочес. 2013. № 1. С. 8-14.

Міненко М.А. Публічне управління: теорія та методологія: монографія. Київ : Київ. нац. торг.-екон. ун-т, 2014. 404 с.

Титаренко Л. Публічні органи влади в контексті вітчизняного суспільнополітичного розвитку. ОРІДУ НАДУ. Електронна збірка ОРІДУ НАДУ. 2018, Вип. № 22. (жовтень). С. 106-115.

Шарий В.I. Сутність надання послуг у публічному управлінні. Публічне управління: шляхи розвитку : матер. наук.-практ. конф. за міжнар. уч. (26 листопада 2014 р., м. Київ) : у 2 т. Т. 1 / за наук. ред. Ю.В. Ковбасюка, С.А. Романюка, О.Ю. Оболенського. Київ : НАДУ, 2014. С. 27-28. 
Здійснення державної влади на засадах основоположних правил, що стосуються прийняття рішень, обсягу повноважень і поділу влади, у політичній системі визначаються Основним Законом (розд. II КУ), що включає положення про правила, норми, процедури та принципи, які передбачають порядок формування, обговорення, прийняття та здійснення державної політики інститутами влади, а також державного управління. Конституція є особливо важливою в політичній системі, що грунтується на верховенстві права. Отже, завданням демократично орієнтованої політичної (державної) влади $\epsilon$ виявлення суспільних проблем і вироблення стратегії щодо їх вирішення. Якщо політична влада невчасно ідентифікує проблеми i не вживає відповідних заходів щодо їх вирішення, то вони набувають загальнонаціональних масштабів, призводячи до конфліктів, криз, революцій, соціальних вибухів, соціальних катастроф. У зв'язку з цим Адміністрація Президента України, Секретаріат Кабінету Міністрів України, відповідні служби органів виконавчої влади та місцевого самоврядування здійснюють моніторинг і формують відповідний список актуальних проблем у державі для його розгляду на найвищому рівні та прийняття рішень 3 кожного питання зокрема ${ }^{3}$.

Аналіз проблем публічного реформування натепер дає можливість відповісти на запитання: Як виникають проблеми? Як проблеми виділяються в політиці? Які дії можливі для вирішення проблем? Які пріоритети дій? Якою має бути система розв'язання проблем? Під час аналізу важливо визначити якість проблем: справжні та несправжні проблеми; проблеми-причини та проблеминаслідки; головні та другорядні проблеми. Із усього списку проблем у державі слід виділити найбільш пріоритетні, що завжди складно, 3 огляду на групові та загальнонаціональні інтереси.

Вважаємо, що державну політику потрібно раціоналізовувати досліджувати і визначати актуальні проблеми, пріоритетні галузі, сфери, яким необхідна державна підтримка й стимулювання, грунтуючись на економічних, соціальних, фінансових, а також

${ }^{3}$ Про схвалення Концепції реформування місцевого самоврядування та територіальної організації влади в Україні : Розпорядження Кабінету Міністрів України № 333-р від 01.04.2014 р. Офіційний вісник України. 2014. № 30. С. 18.

Рекомендація 19 (2001) Комітету міністрів Ради Європи «Про участь громадян у місцевому публічному житті» URL: http://zakon4.rada.gov.ua/ laws/show.

Сорока С. Зеленський і Система: які варіанти розвитку подій. Українська правда від 01 травня 2019. URL: https://www.pravda.com.ua/columns/. 
інших критеріях. Головне - відповісти на питання: чи можна об'єктивно визначити пріоритети державної політики та якою є роль політичних факторів, чи можна виміряти стратегію державної політики та які методи є найбільш надійними для цього.

\section{1. Методологія, теорія та історія державного управління}

Організація системи демократичної, соціально орієнтованої політики держави потребує впровадження ефективних механізмів вітчизняного реформування багатофункціональної політики держави, поліпшення якості життя громадян.

Під державною політикою слід розуміти сукупність ціннісних цілей, державно-управлінських заходів і дій, порядок реалізації державно-політичних рішень у системі державного управління щодо розвитку країни ${ }^{4}$.

Актуальні питання державної політики, іiі теорії, змісту та методології осмислюються крізь призму суспільно-політичних подій і розкриваються в практиці державної політики. При цьому розгляд іiі багатофункціональної сутності супроводжується всебічним аналізом публічної політики у різних сферах суспільного життя, проблематикою регіонального розвитку та місцевого самоврядування.

Доцільно підкреслити, що категорія «демократично оріснтована політика держави» $\epsilon$ складною за своєю сутністю. Натепер зумовленість розвитку орієнтованої політики держави як базової основи реформування державного управління, з одного боку, сприяє назрілим питанням, пов'язаним з проблемами оптимізації публічної влади в контексті соціально-економічної і політичної модернізації України, а $з$ іншого - висуває низку питань, тісно пов'язаних зі станом та вітчизняними тенденціями розвитку.

Визначення змісту діяльності політики держави, державного апарату розкриває, що управлінська, організаційна робота покликана забезпечити організованість і ефективне функціонування всіх сфер громадського життя. Водночас, незважаючи на те, що від початку суспільних перетворень у нашій країні пройшло чимало часу, на жаль, ми стали свідками того, що в українському державно-

${ }^{4}$ Титаренко Л. Публічні органи влади в контексті вітчизняного суспільнополітичного розвитку. ОРІДУ НАДУ. Електронна збірка ОРІДУ НАДУ. 2018. Вип. № 22. (жовтень). С. 106-115 с. 
управлінському просторі Україна до сих пір стоїть на порозі багатьох викликів.

За показниками соціологічних досліджень наприкінці 2019 р. було опитано 2015 респондентів віком від 18 років у всіх регіонах України, за винятком Криму та окупованих територій за вибіркою, що репрезентує доросле населення країни. Критерії оцінки вказують, що 69,9\% опитаних оцінюють нинішню ситуацію в Україні як напружену, ще 23,2\% респондентів взагалі вважають іiі вибухонебезпечною. Лише 5,2\% вказують на те, що ситуація в країні стабільна, а 1,9\% не змогли дати чіткої відповіді на поставлене питання 5

Критеріями у загальновизнаному розумінні $\epsilon$ сукупність внутрішніх та зовнішніх факторів: соціологічне дослідження «Суспільно-політична ситуація в Україні», проведене центром Разумкова, службою «Соціс» та соціологічною групою «Рейтинг» щодо перспектив координації українського суспільства, являє собою певну кількісну та якісну ознаку, на підставі якої оцінюється факт: 54,3\% респондентів визначили воєнний конфлікт на Сході України як основну проблему, що потребує негайного вирішення. Окрім того, зниження купівельної спроможності населення, безробіття, виведення інвестицій з країни збільшує депресивний тиск на діяльність виконавчої влади та місцевого самоврядування. Такі показники і думка визначають рівень і якість управління відповідно до потреб суспільства та ситуації в країні ${ }^{6}$

Оцінюючи, як змінилася ситуація у країні загалом порівняно 3 початком 2019 р., 48\% респондентів вважають, що вона не змінилася, 26\% - що загальна ситуація в країні погіршилася, а 15\% - що покращилася. Серед державних та суспільних інститутів найчастіше довіра висловлюється до Збройних сил України

${ }^{5}$ Київський міжнародний інститут соціології: опитування серед дорослого населення України щодо довіри до політичних діячів, підтримки партій $\mathrm{i}$ політичних лідерів. КМIC (лютий 2019 p). URL: https://www.kiis.com.ua/.

${ }^{6}$ Дацюк С. Суть нинішнього надзвичайного стану в Україні. Українська правда. URL: http://blogs.pravda.com.ua/authors/datsuk/58a6bb95e2919/v.

Київський міжнародний інститут соціології: опитування серед дорослого населення України щодо довіри до політичних діячів, підтримки партій $\mathrm{i}$ політичних лідерів. КМIC (лютий 2019 p). URL: https://www.kiis.com.ua/.

Разумков Центр. Оцінка громадянами ситуації в країні та діяльності влади, рівень довіри до соціальних інститутів та політиків. URL: http://razumkov.org.ua. 
(їм довіряють 70\% опитаних), волонтерських організацій (70\%), Президента України (68\%), Церкви (65\%), Державної служби 3 надзвичайних ситуацій (63\%), добровольчих батальйонів (62\%), Національної гвардії України (58\%), Державної прикордонної служби (57,5\%), 3МІ України (54\%), громадських організацій (51\%).

Недовіра найчастіше висловлюється ЗМІ Росії (не довіряють їм $80 \%$ опитаних), судовій системі загалом (73\%), державному апарату (чиновникам) (68,5\%), місцевим судам (68\%), політичним партіям (66\%), комерційним банкам (66\%), прокуратурі (63\%), Верховному Суду (62\%), Конституційному Суду України (58\%), Антикорупційному суду (57\%), Спеціалізованій антикорупційній прокуратурі (56\%), Національному антикорупційному бюро України (НАБУ) (56\%), Національному агентству 3 питань запобігання корупції (НАЗК) (56\%), Національному банку України $(52 \%)^{7}$.

Характеризуючи дії влади, найчастіше громадяни України вважають, що нова влада намагається покращити ситуацію в країні, але їй це поки що переважно не вдається зробити (таку думку поділяють 44\%, у жовтні 2019 р. так вважали 41,5\% респондентів), $25 \%$ опитаних вважають, що нова влада намагається покращити ситуацію в країні і багато в чому їй це вдається (у жовтні 29\%), і $23 \%$ - що нова влада не намагається покращити ситуацію в країні, а лише імітує зусилля в цьому напрямі (цю точку зору поділяли $20 \%$ опитаних).

Частка респондентів, які відповіли, що дії нової влади виправдали їхні сподівання порівняно з жовтнем зменшилася з 23\% до $17 \%$, незмінною (5\%) залишилася частка тих, хто відповідає, що дії нової влади виявилися кращими, ніж вони очікували, з 9\% до $14 \%$ зросла частка тих, хто заявив, що нова влада не виправдала їхніх сподівань, що від нової влади вони нічого доброго не очікували, отже, так і сталося.

Відповідно, 6\% і 7\% відповіли, що влада виявилася ще гіршою, ніж вони думали. А найчастіше (40\% опитаних у жовтні і $37 \%$

7 Дацюк С. Суть нинішнього надзвичайного стану в Україні. Украӥнська правда. URL: http://blogs.pravda.com.ua/authors/datsuk/58a6bb95e2919/v.

Київський міжнародний інститут соціології: опитування серед дорослого населення України щодо довіри до політичних діячів, підтримки партій $\mathrm{i}$ політичних лідерів. КMIC (лютий 2019 р). URL: https://www.kiis.com.ua/.

Разумков Центр. Оцінка громадянами ситуації в країні та діяльності влади, рівень довіри до соціальних інститутів та політиків. URL: http://razumkov.org.ua. 
громадян у листопаді) дотримуються думки, що занадто рано давати оцінку діям влади 8

Крім того, більшість громадян України вважають, що питання запровадження ринку землі, скасування мораторію на купівлюпродаж землі сільськогосподарського призначення потрібно виносити на всенародний референдум. Такої думки дотримуються $59,3 \%$ респондентів. Чверть населення $(24,4 \%)$ вважає, що це питання не слід виносити на референдум, решта опитаних не визначилися 3 відповіддю. Понад дві третини опитаних $(69,1 \%)$ взяли б участь у такому референдумі, якби він відбувався до найближчої дати опитування. Не взяли б участі $16,0 \%$, а решта опитаних не визначилися з відповіддю9.

Згідно з вищезазначеним констатуємо, що певні труднощі, які характеризуються громадською думкою, вимагають безперервного втручання органів влади на засадах прийняття та реалізації ефективних державних рішень, що має вагоме суспільне значення. Підтримуємо тезу С. Дацюка: «якщо влада знаходиться на боці громади, то вона має виходити з позиції захисту ії довгострокових інтересів, соціальних гарантій та основних цінностей» ${ }^{10}$.

Окрім того, як бачимо, всередині країни відбулись відчутні зміни. Обраний новий Президент України, відбулися дострокові парламентські вибори 2019. Чи не тому одним із засадничих викликів сьогодення, що стоять перед главою держави, є приведення системи публічної влади до відповідних стандартів. Це своєю чергою потребує від управлінців усіх рівнів високого професіоналізму, інноваційного мислення, особистої відповідальності. Необхідно не забувати, що на виборах Президента України у 2019 р. В. Зеленський став черговим несистемним політиком, який отримав політичну владу в результаті демократичних виборів. Вважаємо, як багатофункціональне i багатопланове явище державну політику (формування та іiі реалізацію) доцільно розглядати 3 погляду типології, змісту і використання, як цілеоріснтований процес.

На рис. 1 окреслено багатофункціональність політики.

8 Разумков Центр. Оцінка громадянами ситуації в країні та діяльності влади, рівень довіри до соціальних інститутів та політиків. URL: http://razumkov.org.ua.

9 Там само

${ }^{10}$ Дацюк С. Суть нинішнього надзвичайного стану в Україні. Украӥнська правда. URL: http://blogs.pravda.com.ua/authors/datsuk/58a6bb95e2919/v. 


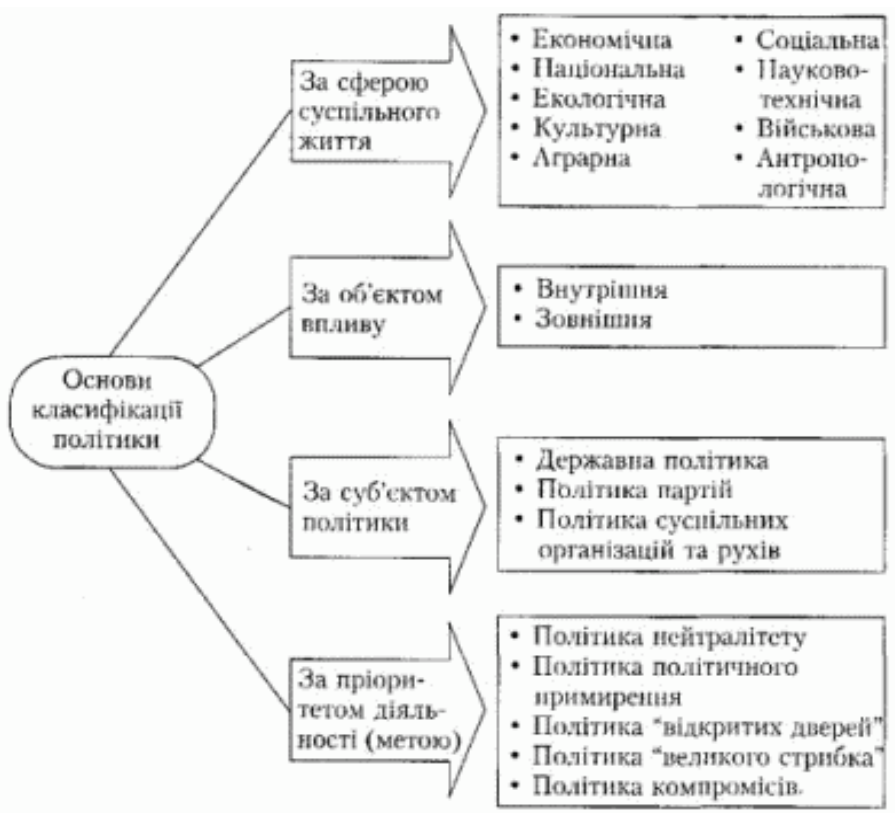

\section{Рис. 1. Багатофункціональність політики}

У змістовому розумінні державна політика може бути прогресивною i регресивною, об'єктивно зумовленою i волюнтаристською, такою, що відповідає назрілим потребам суспільного розвитку та суперечить їм.

3 історії відомо чимало прикладів глибоко хибної політики довільної, реакційної, авантюрної, антинародної, що призводили до страждань i людських жертв. За такого розгляду соціально орієнтований ефект являє собою інтегрований критерій. Це фактично результат, що отримує суспільство в умовах споживання матеріальних, соціальних і духовних цінностей.

Як відзначає С. Сорока (експерт групи «Реформа публічної адміністрації» РПР), поряд із Дональдом Трампом (США) та Еммануелем Макроном (Франція) останнім часом до влади приходили «несистемні політики» в Італії, Ісландії, Грузії, Вірменії, Гватемалі, Ліберії, Маврикії ${ }^{11}$. С. Сорока окреслює проблематику

${ }^{11}$ Сорока С. Зеленський і Система: які варіанти розвитку подій. Украӥнська правда від 01 травня 2019. URL: https://www.pravda.com.ua/columns/. 
того, що в різних випадках ефективність та успішність діяльності публічної влади в різних країнах є різною (на відміну від Польщі, Чехії та країн Балтії, де переважно «несистемні політики» 20-25 років тому забезпечили злам старої авторитарної прокомуністичної системи управління в своїх країнах та провели реальні управлінські реформи) ${ }^{12}$.

Очевидно, несистемність тоді і несистемність зараз загалом $\epsilon$ різною, але разом із тим має спільні ознаки в Україні. Спільним є те, що i тоді, i зараз несистемним новим керівникам держави протистоїть неефективна з точки зору державного управління, зате ефективна 3 точки зору самовідтворення авторитарна чи квазіавторитарна бюрократична система, в якій «друзям - все, ворогам та іншим - закон» 13 .

Таку систему в Україні не можна назвати суто державною, тому що, крім бюрократичних інституцій, іiі стовпами $є$ корупційноолігархічна політична система та корупція, яка іiі живить, i «правоохоронна» та «судова» системи, які ії захищають. Саме такі тенденції демонструють, що питання системних реформ передостанніх років в Україні влада більше імітувала, ніж їх здійснювала, що, очевидно, і стало причиною поразки п'ятого Президента на президентських виборах.

До системних реформ (успішна реалізація яких могла б еволюційним шляхом змінити олігархічно-бюрократичну систему в Україні) належать судова та антикорупційна реформи (які поки що натепер провалені), політична реформа та реформа виборчої системи (провалені), реформа державного управління та державної служби (яка натепер мляво, але рухається), децентралізація + створення ОТГ (мляво, але рухається).

Саме тому головним завданням державної бюрократичної машини було i, на жаль, багато в чому залишається не забезпечення ефективного урядування, а контроль за грошовими потоками для своїх «спонсорів» або невтручання в справи «дорослих» для простих державних службовців ${ }^{14}$.

Головна небезпека полягає в тому, що корупція має тяжкі наслідки для всіх прошарків суспільства, вона деморалізує громадян, руйнує їхню довіру до держави, до лідерів. Вона

\footnotetext{
12 Там само

13 Там само

14 Мельник Р.С. Категорія «публічне управління» у новій інтерпретації. Адміністративне право і процес. 2013. № 1. С. 8-14.
} 
перетворює державу із засобу збалансованого забезпечення потреб усіх соціальних верств на знаряддя захисту інтересів вузьких груп за рахунок усього суспільства. I зі всім цим новообраний Президент В. Зеленський має щось робити.

Видається, що основне призначення державного апарату полягає в забезпеченні високого рівня здоров'я, освіти, добробуту населення, ефективного функціонування держави.

Під час вирішення проблем реформування вища політична еліта країни, представники публічної влади мають впроваджувати нові практики управління на зниження руйнівних тенденцій кадрової чехарди та підвищення ефективності функціонування інституту соціально орієнтованого управління.

Варто пам'ятати, що для сучасної України виклики державотворення були і залишаються складними через тягар минулого та складності сьогодення, відсутності достатніх знань, досвіду та компетенцій новообраних парламентарів.

\section{2. Виклики й потреби розвитку публічного управління}

Аналіз інституційних змін та зумовленість розвитку публічного управління в руслі модернізації країни потребує удосконалення політичної, економічної, соціальної, адміністративної сфер на сучасному етапі. Доцільною $\epsilon$ думка науковців, що розвиток публічного управління, організаційних структур влади, продумана державна політика лідера країни мають спрямовуватись на кадрову політику забезпечення стабільності в політичній, економічній і соціальній сферах, що передбачає запровадження механізмів партнерства соціальних груп та інституцій ${ }^{15}$.

Відповідно, нині в Україні триває процес реформування системи державного управління в напрямі децентралізації, вибору європейського шляху, за якого у вітчизняній сфері управління має відбутися переорієнтація державного управління, місцевого самоврядування на системний розвиток демократично орієнтованої

15 Оболенський О.Ю. Публічне управління: цивілізаційний тренд, наукова теорія і напрям освіти. Публічне управління: иляхи розвитку: матер.наук.-практ. конф. за міжнар. уч. (26 листопада 2014 р., м. Київ) : у 2 т. Т. 1 / за наук. ред. Ю.В. Ковбасюка, С.А. Романюка, О.Ю. Оболенського. Київ : НАДУ, 2014. С. 3-10.

Титаренко Л. Публічні органи влади в контексті вітчизняного суспільнополітичного розвитку. ОРІДУ НАДУ. Електронна збірка ОРІДУ НАДУ. 2018, Вип. № 22. (жовтень). С. 106-115. 
політики держави ${ }^{16}$. Нові механізми модернізації публічного управління, ринку праці та різноманітні інститути суспільства вимагають перетворення системи державного управління (як i всього бюрократичного апарату) на ефективну систему урядування, яка б слугувала людям.

Відомий український вчений у галузі державного управління В. Бакуменко стверджує, що «розуміння сутності державного управління зазнало еволюції внаслідок розвитку демократії як у світі, так зокрема і в Україні. Тому «аспект взаємодії держави i суспільства $є$ доволі важливим, на відміну від традиційного бачення державного управління, як організуючого і регулюючого впливу держави на життєдіяльність людей 3 метою iii впорядкування, зберігання або перетворення, що спирається на іiі владну силу» ${ }^{17}$. Вважаємо закономірним, що натепер одним зі стратегічних завдань $є$ формування нової ідеології функціонування виконавчої влади та місцевого самоврядування як діяльності із забезпечення реалізації прав і свобод громадян, надання якісних публічних послуг. 3 цього приводу, відповідно, має змінитись і сутнісна система публічного управління.

Визначальним критерієм для таких змін є виклики сьогодення, що стоять перед новим керівництвом української держави, запровадження в Україні сервісно-європейських стандартів якісного обслуговування громадян та професійно ефективного функціонування адміністративного і політичного керівництва в країні ${ }^{18}$.

Завданнями публічного управління мають стати синергетичне поєднання концепцій раціональної бюрократії, нового державного менеджменту та доброго врядування, основними 3 яких є: зміна функцій і структури органів виконавчої влади у напрямі уникнення

16 Про схвалення Концепції реформування місцевого самоврядування та територіальної організації влади в Україні : Розпорядження Кабінету Міністрів України № 333-р від 01.04.2014 р. Офіиійний вісник України. 2014. № 30. С. 18.

17 Бакуменко В.Д. Публічне адміністрування як процес вироблення, прийняття та виконання управлінських рішень. Наукові розвідки з державного та муніципального управління : зб. наук. пр. Академії муніципального управління. № 1. (Б. м. : б. в.), 2015. С. 8-26.

18 Вернудіна І.В. Особливості публічного управління в Україні: цивілізаційний поступ та сучасні виклики. Публічне управління: шляхи розвитку : матер. наук.-практ. конф. за міжнар. уч. (26 листопада 2014 р., м. Київ) : у 2 т. Т. 1 / за наук. ред. Ю.В. Ковбасюка, С.А. Романюка, О.Ю. Оболенського. Київ : НАДУ, 2014. С. 30-32. 
дублювання їх повноважень; реформа системи бюджетних видатків та доходів; реформа системи державного регулювання; реорганізація державного контролю; дерегуляція та спрощення управлінських процедур; організація вільного доступу до інформації про діяльність державних органів влади; реалізація механізму державно-громадських консультацій 3 вироблення відповідних рішень; реформування інституту державної служби; реалізації принципу підзвітності та підконтрольності влади громадським організаціям і т. ін. ${ }^{19}$

Разом із тим багатофункціональність політики держави визначає внутрішню диференціацію публічної служби. Двома основними видами публічної служби є служба в органах державної влади (державна служба) та служба в органах місцевого самоврядування (муніципальна служба). Принципових відмінностей у службовій діяльності державних службовців та службовців місцевого самоврядування немає. Певним чином ці критерії можна назвати вторинними, тому що фактично організаційні засади управління потребують фахового аналізу та наукових прогнозів, а також критичного переосмислення.

Аналіз соціально-політичної взаємодії представників владних структур досліджується в роботах С. Адамчук, В. Бакуменка, Р. Войтович, М. Міненко, С. Романюка, О. Рудіка, С. Серьогіна, О. Оболенського та ін. У науковій літературі розкривається проблематика гармонізації державних інтересів та інтересів суспільства, що базуються на законодавчих нормах ${ }^{20}$.

19 Гавкалова Н.Л. Публічне управління: методологічний аспект. Публічне управління: иляхи розвитку: матер. наук.-практ. конф. за міжнар. уч. (26 листопада 2014 р., м. Київ) : у 2 т. Т. 1 / за наук. ред. Ю.В. Ковбасюка, С.А. Романюка, О.Ю. Оболенського. Київ : НАДУ, 2014. С. 16-18.

Дацюк С. Хронічна політична криза.: Українська правда від 22 квітня 2016. URL: http://blogs.pravda.com.ua/authors/datsuk/.

${ }^{20}$ Міненко М.А. Публічне управління: теорія та методологія : монографія. Київ : Київ. нац. торг.-екон. ун-т, 2014. 404 с.

Оболенський О.Ю. Публічне управління: цивілізаційний тренд, наукова теорія і напрям освіти. Публічне управління: иляхи розвитку : матер.наук.-практ. конф. за міжнар. уч. (26 листопада 2014 р., м. Київ) : у 2 т. Т. 1 / за наук. ред. Ю.В. Ковбасюка, С.А. Романюка, О.Ю. Оболенського. Київ : НАДУ, 2014. С. 3-10.

Рекомендація 19 (2001) Комітету міністрів Ради Європи «Про участь громадян у місцевому публічному житті». URL: http://zakon4.rada.gov.ua/ laws/show. 
На підставі вищезазначеного варто зауважити, що демократично орієнтована політика держави реалізується крізь публічну службу. Вперше термін «публічна служба» в сучасній Україні на законодавчому рівні використано Кодексом адміністративного судочинства України (докум. 2747-15, поточна редакц. від 05.01.2017), де визначено, що публічна служба - це діяльність на державних політичних посадах, професійна діяльність суддів, прокурорів, військова служба, альтернативна (невійськова) служба, дипломатична служба, інша державна служба, служба в органах влади, органах місцевого самоврядування ${ }^{21}$. Очевидно, це визначення $є$ надмірно широким і викладено в цілях цього Кодексу. Адже від публічної служби, як мінімум, необхідно відокремлювати діяльність політиків на державних політичних посадах та суддів, позаяк за своєю природою ці посади не є службовими.

Треба зазначити, що для оцінки діяльності органу влади, а також формування умов праці та реалізації державно-службових відносин розроблятимуться та вдосконалюватимуться норми і стандарти надання послуг, професійно-кваліфікаційні характеристики посад та посадові інструкції.

Таким чином, до поняття «публічна служба» включають діяльність працівників інституцій, які виконують публічні завдання, в тому числі діяльність державних або муніципальних лікарів, учителів тощо. Під час вибору підходу до розуміння суті публічної служби варто керуватися потребами практики. Чи не тому найбільш раціональним $\epsilon$ інституційний підхід, який окреслює сферу публічної служби рамками публічної адміністрації, тобто в Україні це насамперед органи виконавчої влади та органи місцевого самоврядування.

Демократична орієнтованість політики держави впливає на розвиток таких важливих сфер, як політична, освітня, наукова, охорони здоров'я, соціального захисту громадян, рівня економічних показників тощо. Разом із тим, визнаючи публічне управління як явище складне і багатогранне, більшість учених вказують на те, що поки що немає сталого, вичерпного його формулювання. Багатофункціональність політики держави вчені розглядають із

21 Кодекс адміністративного судочинства України. Документ 2747-IV, попередня редакція - від 05.01.2017, підстава - 1798-VIII. 
позицій інституційної діяльності публічного управління. Так, на думку Р. Мельник, «публічне управління» зорієнтоване на реалізацію публічних (загальних) інтересів i включає такі складники, як: державне управління (суб'єктом є органи державної влади) i громадське управління (суб'єктом є громадські інституції) $^{22}$.

Як елементи публічного управління державне і громадське управління взаємодіють, взаємодоповнюють одне одного, виходячи з єдності публічних політико-управлінських інтересів та доцільності узгодження впливу з метою посилення його дієвості. Це своєю чергою потребує заохочення управлінців усіх рівнів до спроможності безперервного підвищення освітнього рівня, удосконалення професійних знань.

Розуміння багатофункціональності політики публічного управління як процесу, що здійснюється на основі волевиявлення громади (колективу людей) та реалізується фаховими суб'єктами, знаходимо у професора О. Оболенського ${ }^{23}$. Інший український учений В. Авер'янов розглядає публічне управління як «владноорганізуючий вплив керуючих суб'єктів на спільну діяльність людей з метою їх упорядкування, координації та спрямування задля ефективного досягнення загальних (спільних) цілей і завдань цієї діяльності» ${ }^{24}$. Автори наукових матеріалів акцентують увагу на тому, що демократично орієнтована політика в забезпеченні прав громадян є основою благополуччя та гідного життя кожної людини.

\section{ВИСНОВКИ}

Загалом видається, що найбільш важливими характеристиками державної демократично орієнтованої політики мають бути: реагування на зміни, що відбуваються в суспільстві; комплексний

${ }^{22}$ Мельник Р.С. Категорія «публічне управління» у новій інтерпретації. Адміністративне право і прочес. 2013. № 1. С. 8-14.

${ }^{23}$ Оболенський О.Ю. Публічне управління: цивілізаційний тренд, наукова теорія і напрям освіти. Публічне управління: шляхи розвитку: матер.наук.практ. конф. за міжнар. уч. (26 листопада 2014 р., м. Київ) : у 2 т. Т. 1 / за наук. ред. Ю.В. Ковбасюка, С.А. Романюка, О.Ю. Оболенського. Київ : НАДУ, 2014. C. $3-10$.

${ }^{24}$ Авер'янов В.Б. Державне управління: європейські стандарти, досвід та адміністративне право / В.Б. Авер'янов, В.А. Дерець, А.М. Школик та ін. ; за заг. ред. В.Б. Авер'янова. Київ : Юстиніан, 2007. 288 с. 
підхід і розгляд кожної проблеми у взаємозв'язку з іншими проблемами. Державна політика має розроблятися та реалізовуватися на кількох щаблях залежно від масштабів розв'язуваної проблеми або охоплення суспільної сфери.

В Україні дослідження і аналіз державної політики у сфері публічного реформування проводяться в рамках галузі науки «державне управління». Розробка та введення нових норм 3 урахуванням перспективних i першочергових пріоритетів демократичної системи визначає цілі, стратегію політики, функції об'єктів політики, методи ії реалізації. Як наслідок, запровадження адміністративної реформи, формування механізму правової держави та державного апарату органічно пов'язані 3 демократично орієнтованою політикою держави.

Орієнтованість політики спрямовується в напрямі публічного реформування вищими органами державної влади 3 окресленням основних ознак громадської думки.

Це має бути комплексний стратегічний підхід, а у його центрі базові інтереси суспільства, стратегічні потреби розвитку держави у формі основних принципів і цілей. Усе це зобов'язує інститути влади цілеспрямовано вести країну шляхом демократично орієнтованих реформ.

Тому визначення стратегічних напрямів політичної модернізації управління за кращими європейськими та світовими стандартами вимагає соціально справедливого багатофункціонального управління державою, яке б забезпечило гармонізацію державних інтересів та інтересів суспільства.

\section{АНОТАЦІЯ}

У статті теоретично узагальнено демократичну орієнтованість політики держави в напрямі публічного реформування. На основі ознайомлення i аналізу інформаційних джерел висвітлено спрямованість державних інституцій у сфері державно-публічного управління.

Окреслюючи удосконалення демократичної спрямованості політики держави, розкривається зміст того, що у суспільнополітичному житті влада посідає особливе місце.

При цьому розкриття змісту демократичної орієнтованості політики держави полягає в такому: влада виступає як необхідна 280 
умова існування й розвитку суспільства. Це пов'язано з тим, що вона віддзеркалює об’єктивну потребу в організації, задоволенні прагнень саморозвитку і цілісності суспільства. Саме влада $\epsilon$ сполучною ланкою системи, яка визначає iї природу і стійкість.

3 теоретико-правового погляду у демократичному суспільстві, де джерелом влади та іiі носієм є народ, демократично орієнтовна політика держави проявляється діями влади, себто діяльності, спрямованої на досягнення консенсусу між різними політичними силами i розвитком суспільства 3 метою досягнення його стабільності і порядку, керованості та регульованості.

Саме через механізми політичної влади, засоби іï реалізації відбувається публічно-управлінський процес ефективності розвитку держави, вирішуються завдання розвитку суспільства. I саме боротьба за владу та іï утримання або за вплив на неї становлять основний зміст політики. Ось чому ключ до розуміння публічного управління і політики реформування полягає в реальній практиці демократизації суспільства.

\section{ЛІТЕРАТУРА}

1. Авер'янов В.Б. Державне управління: європейські стандарти, досвід та адміністративне право / В.Б. Авер'янов, В.А. Дерець, А. М. Школик та ін. ; за заг. ред. В.Б. Авер'янова. Київ : Юстиніан, 2007. 288 c.

2. Бакуменко В.Д. Публічне адміністрування як процес вироблення, прийняття та виконання управлінських рішень. Наукові розвідки з державного та мунічипального управління : зб. наук. пр. академії муніципального управління. № 1. (Б. м. : б. в.), 2015. C. 8-26.

3. Енциклопедичний словник з державного управління / уклад. : Ю.П. Сурмін, В.Д. Бакуменко, А.М. Михненко та ін. ; за ред. Ю.В. Ковбасюка, В.П. Трощинського, Ю.П. Сурміна. Київ : НАДУ, 2010. $820 \mathrm{c}$.

4. Вернудіна І.В. Особливості публічного управління в Україні: цивілізаційний поступ та сучасні виклики. Публічне управління: шляхи розвитку : матер. наук.-практ. конф. за міжнар. уч. (26 листопада 2014 р., м. Київ) : у 2 т. Т. 1 / за наук. ред. Ю.В. Ковбасюка, С.А. Романюка, О.Ю. Оболенського. Київ : НАДУ, 2014. С. 30-32. 
5. Войтович Р.В. Ефективність публічного управління в умовах пошуку нової геополітичної ідентичності України. Публічне управління: шляхи розвитку : матер. наук.-практ. конф. за міжнар. уч. (26 листопада 2014 р., м. Київ): у 2 т. Т. 1 / за наук. ред. Ю.В. Ковбасюка, С.А. Романюка, О.Ю. Оболенського. Київ : НАДУ, 2014. Т. 1. С. 30-34.

6. Гавкалова Н.Л. Публічне управління: методологічний аспект. Публічне управління: шляхи розвитку : матер. наук.-практ. конф. за міжнар. уч. (26 листопада 2014 р., м. Київ) : у 2 т. Т. 1 / за наук. ред. Ю.В. Ковбасюка, С.А. Романюка, О.Ю. Оболенського. Київ : НАДУ, 2014. С. 16-18.

7. Дацюк С. Хронічна політична криза. Украӥнська правда від 22 квітня 2016. URL: http://blogs.pravda.com.ua/authors/datsuk/.

8. Дацюк С. Суть нинішнього надзвичайного стану в Україні. Українська правда. URL: http://blogs.pravda.com.ua/authors/datsuk/ 58a6bb95e2919/v.

9. Київський міжнародний інститут соціології: опитування серед дорослого населення України щодо довіри до політичних діячів, підтримки партій і політичних лідерів. КMIC (лютий 2019 р). URL: https://www.kiis.com.ua/.

10. Кодекс адміністративного судочинства України. Документ 2747-IV, попередня редакція - редакція від 05.01.2017, підстава 1798-VIII.

11. Мельник Р.С. Категорія «публічне управління» у новій інтерпретації. Адміністративне право і процес. 2013. № 1. С. 8-14.

12. Міненко М.А. Публічне управління: теорія та методологія : монографія. Київ : Київ. нац. торг.-екон. ун-т, 2014. 404 с.

13. Оболенський О.Ю. Публічне управління: цивілізаційний тренд, наукова теорія і напрям освіти. Публічне управління: шляхи розвитку : матер. наук.-практ. конф. за міжнар. уч. (26 листопада 2014 р., м. Київ) : у 2 т. Т. 1 / за наук. ред. Ю.В. Ковбасюка, С.А. Романюка, О.Ю. Оболенського. Київ : НАДУ, 2014. С. 3-10.

14. Про схвалення Концепції реформування місцевого самоврядування та територіальної організації влади в Україні : Розпорядження Кабінету Міністрів України № 333-р від 01.04.2014 р. Офіиійний вісник України. 2014. № 30. С. 18.

15. Рекомендація 19 (2001) Комітету міністрів Ради Європи «Про участь громадян у місцевому публічному житті». URL: http://zakon4.rada.gov.ua/laws/show. 
16. Сорока С. Зеленський і Система: які варіанти розвитку подій. Українська правда від 01 травня 2019. URL: https://www.pravda.com.ua/columns/.

17. Стадник М.М. Публічне управління як чинник сталого розвитку. Публічне управління: иляхи розвитку : матер.наук.-практ. конф. за міжнар. уч. (26 листопада 2014 р., м. Київ) : у 2 т. Т. 1 / М.М. Стадник, В.С. Дяченко; за наук. ред. Ю.В. Ковбасюка, С.А. Романюка, О.Ю. Оболенського. Київ : НАДУ, 2014. С. 39-41.

18. Титаренко Л. Публічні органи влади в контексті вітчизняного суспільно-політичного розвитку. ОРІДУ НАДУ. Електронна збірка ОРІДУ НАДУ. 2018, Вип. № 22. (жовтень). С. 106-115.

19. Шарий В.I. Сутність надання послуг у публічному управлінні. Публічне управління: шляхи розвитку : матер. наук.практ. конф. за міжнар. уч. (26 листопада 2014 р., м. Київ): у 2 т. Т. 1 / за наук. ред. Ю.В. Ковбасюка, С.А. Романюка, О.Ю. Оболенського. Київ : НАДУ, 2014. С. 27-28.

20. UN Public Administration Glossary. URL: http://www.unpan.org/ DPADM/ProductsServices/.

21. Pollitt C. Public Management Reform: A Comparative Analysis / C. Pollitt, G. Bouckaert. Oxford : University Press, 2004. Pp. 12, 13.

22. Bouckaert G. Modernizing the Rechtsstaat: Paradoxes of the Management Agenda. Berlin : Duncker \& Humblot, 2002. P. 26.

23. Стратегія реформування державного управління України на період до 2021 року : Розпорядження Кабінету Міністрів України (від 18 грудня 2018 р. № 1102-р).

24. Разумков Центр. Оцінка громадянами ситуації в країні та діяльності влади, рівень довіри до соціальних інститутів та політиків. URL: http://razumkov.org.ua.

\section{Information about authors: Tytarenko L. M., \\ Candidate of Political Science,} Associate Professor of the Department of Humanities and Socio-Political Sciences Odessa Regional Institute for Public Administration of the National Academy for Public Administration under the President of Ukraine 22, Henuezka Str., Odesa, Ukraine, 65009 
Hrishyn O. V.,

Postgraduate Student in the Department of State Studies and Law

Odessa Regional Institute for Public Administration of the National Academy for Public Administration under the President of Ukraine 22, Henuezka Str., Odesa, Ukraine, 65009 